\title{
Uma estranha companheira
}

\author{
A strange companion
}

\section{Fernanda Alves Afonso Grieben}

As ruas por onde passo, todos os dias, ainda são as mesmas da minha infância, só mais degradadas. Os rostos com que me cruzo, esses são bem diferentes. E eu pergunto-me: "O que resta dos semblantes de outrora, quando o mar se espelhava nos olhares dos passantes, e ser português era transportar na alma a chama da esperança de uma vida melhor?" E o vento, sempre atento às mudanças a que preside, sopra agreste no meu próprio rosto, os meus cabelos desgrenhando, à medida que caminho.

Está frio. É Inverno. A humidade do ar que respiro entranha-se nos meus pulmões, juntamente com os odores indesejáveis da viela por onde passo, neste momento.

Este troço da minha rua é pouco visitado. As pessoas evitam-no, como se evita a peçonha. Habitam-no os gatos vadios, que nele dejetam. Passam por aqui os cães abandonados no último Verão, antes das férias de seus antigos donos, e eu.

De olhos atentos, postos na calçada, caminho, desviando-me das manchas de urina e das fezes. "Mas porque terei de passar sempre por aqui?", pergunto-me. "É mais rápido", justifico. Mas será esta a verdadeira razão? Esta minha necessidade, quase masoquista, de passar por esta rua de amarguras, sem que nada a tal me obrigue, é uma verdadeira irracionalidade. Que terá o meu coração a dizer acerca disto? Serão as lembranças do passado que para aqui me conduzem, quando deste lugar os meus passos se aproximam?

Chego a uma Praça. Paro no cruzamento, esperando o sinal verde, para poder atravessar a rua em direção à igreja. Terá um nome? Nunca soube. Também nunca me interessou. Mas agora, espontaneamente, surge em mim o desejo de o saber: "Como se chamará?"

Este edifício, antigo, é um marco incontornável, se revisito a minha infância. Vivi aqui, neste largo, num prédio que pouco dista da igreja. Entretanto é um prédio velho, e a fachada tem muito mau aspeto. "Pois é, já tem quase cinquenta anos... Como o tempo passa!", apercebo-me então.

Mas a igreja, essa continua com o mesmo aspeto exterior.

\author{
$\diamond$
}

Atravesso a rua e entro no seu interior. "Continua igual! Por este edifício, parece que o tempo não passou...", concluo.

Observo as imagens: do lado esquerdo, logo à entrada, a de santo António de Lisboa, com o seu hábito castanho de frade franciscano, cordão branco à cinta. Um pão, numa das mãos. O pão dos pobres.

"E pobres não faltam....", medito de coração triste, "só é pena que o pão não se multiplique... Mas também que adiantava?... É um pão de pedra!"

De repente, tomo consciência de que é frio o edifício onde me encontro. Cheira a lavado de fresco, o pavimento, que ainda está húmido. Os bancos são negros, de madeira envernizada. Encostado a uma parede, dobrado, um confessionário desdobrável lembra-me um antiquíssimo leque de dama, de invulgar tamanho.

Que estranha companheira é esta, a Memória. Torna vivas imagens já apagadas. Ressuscita mortos. E, num instante mágico, me transporta para um passado-presente.

O confessionário, agora desdobrado, está colocado na passagem estreita que fica entre a parede e os bancos negros da igreja. Dentro dele, um padre já idoso que, em curtos intervalos de tempo, mostra a cabeça quase calva, desviando a cortina encarnada com uma das mãos, enquanto a outra enxuga com um lenço a transpiração da nuca. Controla o tamanho da fila onde me encontro, há tempos infinitos, com as minhas colegas da escola primária.

Aproxima-se a Páscoa. E a professora, que nos acompanha, está aqui para se certificar de que cumpriremos o nosso dever cristão.

É a primeira vez que me é permitido confessar-me, juntamente com as minhas colegas de escola, apesar de já ter oito anos de idade e de frequentar a terceira classe. Não fiz a Primeira Comunhão no tempo certo. Por isso, no ano anterior, antes da partida para a igreja, eu encontrome à frente da classe, no estrado onde está colocada a secretária da professora e o quadro negro, integrando um pequeníssimo grupo de alunas.

- São estas as que restam. Não fizeram a Comunhão. São protestantes! - afirma a professora, com um tom de 
acusação na voz, esclarecendo a servente que tem de tomar conta de nós, enquanto as outras alunas se vão confessar.

"O que significará ser protestante? Significará que protestamos?", interrogo-me em pensamento, enquanto observo as minhas companheiras do grupo. São duas, mas... "Quem são, ao certo? Não me lembro de alguma vez ter brincado com elas. Parece-me, até, que estou a vê-las pela primeira vez. Será que já estamos juntas desde a primeira classe?" Não consigo ter certezas.

A situação é estranha, para mim. Faço parte, inesperadamente, de um pequeníssimo grupo que restou, e com o qual eu tenho algo que desconheço em comum. "O que significará ser protestante?"

Este ano, porém, estou na fila. E que angústia se apodera do meu coração, quando chega a minha vez de me aproximar do confessionário. "E se me esqueço de algum pecado? Quantos eram?" Conto pelos dedos, para ter a certeza de que não me esqueço de nenhum, à medida que vou caminhando, lentamente.

Chego ao confessionário, e ajoelho-me.

- Perdoai-me padre porque pequei - digo com uma voz um tanto trémula.

Não recebo qualquer resposta.

Repito a afirmação. Mas, nada! Dos orifícios da negra placa de madeira talhada, nenhum som saía.

"Será que o padre careca ainda está lá dentro? Será que saiu sem eu dar por ela?", interrogo-me, desesperada. "E agora, o que é que eu faço? Estou metida numa alhada!"

Tento espreitar pelos orifícios. Que escuridão! Não se vê nada... Dou umas pancadinhas na madeira com a mão direita fechada, e pergunto em voz baixa:

- Está aí alguém?

Não me é dirigida qualquer resposta, mas desta vez, de ouvido mais atento, parece-me ouvir alguém respirar, de forma um tanto ofegante, dentro do confessionário. Fico mais aliviada, e resolvo desafiar de novo a minha sorte:

- Perdoai-me padre porque pequei - digo com uma voz um pouco mais confiante.

- Já disseste isso três vezes!! Pensas que sou surdo?? Continua! - Grita-me o padre, lá de dentro, furioso.

Terror apodera-se do meu ser. Fiz tudo errado! "Como é que era?... ele não deveria ter respondido já não sei o quê?..."

- Como é que continuo? - pergunto-lhe amedrontada.

- Diz os teus pecados!! - grita o padre, ainda mais furioso.

Desgraça total! Com tantos gritos e terrores, os pecados tinham desaparecido todos do meu cérebro, não restava um único, por mais insignificante que fosse. Fico muda.

- Então?! Não dizes nada? Pensas que vamos ficar aqui o dia todo?! - pergunta o padre, num tom tão alto de voz, que eu penso que, entretanto, já se deve ouvir na rua. Não me atrevo a olhar sequer para o lado. Só para a placa de madeira negra que tenho à minha frente.

- Não me lembro de nenhum... esqueci-me... digo-lhe, por fim, com a voz a tremer.

- Não tens pecados, é?! Não tens pecados?! És santa, és?! És alguma santa?!

"Santa!... Santa!...", ouço em forma de eco, dentro da minha cabeça. "Ser santa é não ter pecados", compreendo pela primeira vez. "Mas... o que são pecados? Tenho pecados?", interrogo-me, escutando-me no mais íntimo do meu ser.

Encontro um silêncio feito de vazio. E o meu corpo, que ainda há poucos instantes, pesado, já ardia no fogo do inferno, sinto-o agora leve como uma pena. "Onde estão os meus pecados? Se os tenho, onde estão? Onde se esconderam?" Não os encontro. "Que horror! Se calhar sou santa!"

O padre continua aos gritos. Não sei o que diz. Os meus ouvidos recusam-se a ouvi-lo. Ausentaram-se. Ou melhor, já só ouvem o diálogo desesperado que travo comigo mesma.

É um curto diálogo, mas decisivo. Percebo que os pecados que eu tinha recolhido nos últimos dias, através do interrogatório que efetuara a familiares próximos, não eram meus de verdade. "Quais eram?..." Vem-me então o primeiro à memória. Foi a minha mãe quem mo tinha sugerido. Digo-o espontaneamente em voz alta:

- Bato no meu irmão.

O padre tenta dizer alguma coisa, mas eu interrompo-o, apressando-me a acrescentar:

- Mas é sempre ele que começa! E eu só lhe bato porque ele me bate a mim primeiro, e com mais força.

"Está justificado o pecado, que, afinal de contas, não é bem um pecado, porque quem tem sempre culpa é o meu irmão, que nunca me deixa em paz", penso para comigo, esperando receber a absolvição, para me poder ir embora. Mas engano-me. Seja por que razão for, o padre está cada vez mais zangado comigo. Já não há nada a remediar. Já nem me interessa se mais alguém está a ouvir os gritos. Um único pensamento domina agora o meu cérebro: "Como posso desaparecer daqui o mais depressa possível?" Lembro-me de mais um pecado e atiro-o pela boca fora:

- Às vezes esqueço-me de ir à Missa!

"Com este pecado devo estar salva", penso. "Afinal este foi-me sugerido pela minha avó, que reza o terço o dia todo, a um número infinito de santos", pondero, em silêncio.

- É tudo?! Não tens mais pecados?! - grita mais uma vez o padre, insatisfeito com o meu novo silenciar.

- Não. Quer dizer... eram três, mas já não consigo lembrar-me do terceiro. 
Mais colérico do que nunca, o padre faz-me saber a penitência que tenho de cumprir:

- Vais à imagem da Nossa Senhora, e vais rezar lá, ajoelhada, três pai-nossos e cinco ave-marias.

Levanto-me apressada, mas ainda não me desviei do confessionário, e já o homem grita de novo:

- Espera! Não! Reza antes dez ave-marias e cinco pai-nossos.

Desloco-me a passo rápido em direção à imagem da Nossa Senhora, que está colocada num pequeno altar. Ajoelho-me. Observo a imagem. Penso na penitência: "Tantas ave-marias! E eu que só gosto do pai-nosso... será que posso trocar as ave-marias por pai-nossos? Porque é que não havia de poder?! Mas... quantas avemarias vale um pai-nosso? Duas? Não, é de menos. Três...? Quatro...?"

Faço cálculos mentais. Reflito, e concluo: "Um painosso vale pelas dez ave-marias. Se é a única oração que Jesus nos ensinou - como me disseram -, então vale muito mais que todas as outras. Dá, então, seis pai-nossos."

Contas feitas, começo a rezar, olhos fixos no rosto da Nossa Senhora. O mesmo rosto que já tinha observado no Domingo anterior, de todos os pontos de vista possíveis, durante longo tempo, depois da Missa.
Queria descobrir se ela também seria capaz de sorrir para mim, como sorria para uma vizinha, sensivelmente da minha idade, com quem eu brincava. Mas... nada! Para mim, os lábios não se mexiam nem um bocadinho.

"Quem terá razão? Será a avó dessa minha amiga, que diz que é normal que a Nossa Senhora sorria quando as crianças a observam, porque as crianças não têm maldade; ou será a minha mãe, que me diz que é a minha colega de brincadeira que tem fantasia de mais e juízo de menos?" Difícil de descobrir.

Observo atenta e pormenorizadamente a Nossa Senhora, enquanto rezo.

Observo os seus pés descalços, as mãos delicadas, o véu comprido. Estas imagens misturam-se na minha mente com as palavras da oração que digo em voz baixa: Pai Nosso que estais no céu, santificado seja o vosso Nome...

E num momento - num simples momento -, os meus olhos abrem-se, e eu vejo, agora, que a Nossa Senhora a quem dirijo a minha oração é só uma imagem esculpida em madeira...

Recebido: 07/12/16

Aprovado: 30/03/17

Contato: fe@revisitar.com 